Conference Report

\title{
Augustine, Addiction and Lent: A Pedagogic Exercise
}

\author{
Maria Poggi Johnson \\ Department of Theology/Religious Studies, University of Scranton, Scranton, PA 18510, USA; \\ E-Mail: maria.johnson@scranton.edu; Tel.: +1-570-969-0472; Fax: +1-570-941-4309
}

Academic Editors: Scott McGinnis and Chris Metress

Received: 20 January 2015 / Accepted: 13 February 2015 / Published: 25 February 2015

\begin{abstract}
The article describes a series of pedagogic exercises developed to help students in a General Education course at a Jesuit university to engage fruitfully with Augustine's Confessions in a way that will facilitate and deepen their understanding of a classic text of the Western tradition and, at the same time, promote their personal formation in keeping with the goals of Ignatian pedagogy.
\end{abstract}

Keywords: Augustine; pedagogy; core texts/great books programs; history of Christianity

Teaching has many great pleasures. However, it also has its share of small but exquisite pains. One of those that has particularly tormented me in recent years, as it has become increasingly popular with my students, is the word "relatable".

Much as I loathe the word itself, I do have sympathy for what my students use it to express. One of the most rewarding facets of teaching at a Jesuit institution like mine is Ignatian pedagogy's embrace of cura personalis: the care and education of the whole person, emotional, moral and spiritual as well as intellectual. As faculty we are not only permitted but actively encouraged to form rather than merely to inform our students. This formation, naturally, can best be done-indeed can only be done-with the willing cooperation of the students. Therefore, at least some texts and topics need to be "relatable", to address questions that already engage or preoccupy our students, whether or not they are explicitly aware of it. This, of course, can be managed: the challenge lies in finding texts that are both "relatable" and intellectually serious, that can engage the students without compromising the integrity of classroom or academic discipline.

What could meet this challenge more perfectly than the Confessions? In it Augustine tells the story of his long, winding, and often tormented path to the church. He recalls his feelings, motivations and conflicts at every stage and interrogates better to understand the human condition in relation to God, in 
whom he eventually finds peace. With the Confessions in hand, we can stand in front of a classroom of young people who are finding their way, amid uncertainties, distractions, and mistakes, towards their adult selves, reaching for a clear understanding of their desires, their priorities, their motivations, their happiness, the role of love and sex and meaning in their lives, and we can tell them, "Here, guys. This is one of the classics not only of the Christian intellectual tradition, but of all of Western literature. It is about a young man finding his way, amid uncertainties, distractions and mistakes, towards his adult self, reaching for a clear understanding of his desires, his priorities, his motivations, his happiness, the role of love and sex and meaning in his life" Could there be a greater gift to teacher and students both? And yet, the first time I assigned it for "Introduction to Christian Theology" (the course is required of all students at my institution: the second part of a sequence that begins with "Introduction to the Bible"), the response was as unmistakable as it was incomprehensible. Augustine was "not relatable".

After my initial bewilderment and frustration at this response I rallied. I have introduced into the class a series of pedagogic exercises designed to help the students make an explicit personal connection to some sections and topics of the Confessions, with the goal of opening them to the text as a whole. This essay will describe these exercises.

The series begins with Augustine's discussion in Book I of his childhood education. "I was not fond of study", he writes, "and hated being driven to it. Driven I was, though and that did me good, though my own attitude was far from good, for I learned only under compulsion" ([1], I 12.19). This, at least, is instantly "relatable", and opens a class discussion of students' own experience of education. Do they enjoy learning? If not, why not, and why, then, are they in college? What internal and what external forces motivate them to study? Unsurprisingly, perhaps, many students are considerably more attuned to the latter than to the former. They are very aware that possession of a college degree is essential for access to the kind of adult life they intend for themselves. However, the conversation draws their attention to topics of which they are less aware. How, beyond the business of "getting a job", might the process of earning that degree equip them to live that life? What value might their education might have beyond that of facilitating certain practical goals? We discuss what Augustine says about the enduring value of the lessons he so resented in his youth. "[B]y means of them", he says, "I was gradually being given a power which became mine and still remains with me: the power to read any piece of writing I come across and to write anything I have a mind to myself" ([1], I 13.20). Does the ability to understand and to articulate any point one comes across seem immensely empowering and liberating?

This first conversation is informal. Its goal is simply to initiate, early in the semester (Confessions is the first text we read), a conversation that ties reflection on the text to self-reflection on the part of the students. The second stage in the series of exercises is structured more formally and arises from our reading of the episode beginning in ([1], II 4.9) — one of the most famous in the book. As an adolescent Augustine and his friends stole pears from a neighbor's orchard. Years later, the adult Augustine devotes several pages to puzzling over this escapade Why did he do it? He writes that "Those pears were beautiful, but they were not what my miserable soul loved. I had plenty of better ones, and I plucked them only for the sake of stealing, for once I picked them I threw them away" ([1], II 6.12). What could have induced him to sink to such "abysmal depth", to be so "in love with my own ruin"? ([1], II 4.9) 
My students' initial response to this passage varies between puzzlement and scorn that Augustine is "beating himself up" so much over so seemingly trivial an incident. To try to make sense of the episode, they offer various strategies, most involving some form of the notion that "back then" people took religion more seriously, or moral standards in society were higher, or people's vision of God was more threatening, with the consequence that they sinned less and felt guiltier about it than we do "nowadays", (nowadays being both laxer and more enlightened.) Their explanations then, focus on the fact that Augustine is different from us: not relatable.

I argue, from the text, that stealing the pears was not in itself a major incident in Augustine's life. It interests him as an occasion to explore the universal question of why we do things we really do not want to do. He initially reflects that he "feasted on the sin, nothing more... it was only the criminal act that lent it savor" ([1], II 6.12) but is convinced that in any human act some good is being sought, however perversely. He concludes that the motivation was the thrill of camaraderie, of friendship, albeit "an exceedingly unfriendly form of friendship" ([1], II 9.17). "I would not have done that deed alone" ([1], II 9.17). However, the explanation meets with limited success: my students are still distracted from Augustine's subtle reflections on motivation by the strangeness of a grown man fretting over a few pieces of pilfered fruit. This is clearly just Augustine being weird.

At this point I hand out $4 \times 6$ index cards. I tell the students, "write down the last time you made a decision that you think was bad. When have you chosen to do something that you thought was wrong or knew wasn't really going to make you happy?" The classroom immediately becomes very quiet. When people have finished, I collect the index cards in a bag, shuffle them, redistribute them randomly, and each student reads aloud the one they have drawn. Many of the "confessions" are about time-management and procrastination. Some involve drugs and alcohol, some sex and relationships. Some are worrying: I always make it clear that I am available to talk. Usually one or two lead to a burst of laughter.

This is one of those rare moments in the classroom when every student is listening with rapt attention. The experience is powerful, I think, as all of the responses are read is a group portrait emerges of the class as a collection of individuals variously flawed, confused, conflicted, prone to act against our own better judgment. When we have illustrated and acknowledged collectively and concretely one of Augustine's central insights - that we are mysteries to ourselves, uncertain about our own motivations, given to flouting our own reason, values, desires - the students are more inclined to give Augustine a hearing. After discussing this, I ask them to apply it to what they wrote earlier: what good were you pursuing when you made the choice that you identify as bad? Why do you say that it is a lesser good? What is the good that you wish you had been pursuing instead? Why do you think that is better? Our previous act of collective self-exposure has generated a feeling of trust, even of intimacy, in the classroom, and there are generally students who are willing to volunteer their own experiences: for instance, the satisfaction of leveling up on the video game versus the greater but more distant satisfaction of getting a good grade because of the extra hour spent editing the essay or studying for the test. The effect of this exercise, at least for those students who are ready to engage sincerely with it, is to counteract their defensive tendency to roll their eyes at Augustine for "getting all freaked out about the pears". As we proceed with the book, we refer back to this experience as a reminder that for all the strangeness of his culture, Augustine's story can bring into focus for us aspects of our experience that we might otherwise not notice explicitly. 
The next exercise in the series comes with Book VIII and Augustine's treatment of the divided will. By this point Augustine is 32. From the perspective of my students, this looks like extreme old age. Surely, by thirty-two, they will have it all figured out. At all events they will be well launched in life and progressing with their professional lives. In one sense Augustine is very much where they hope to be: has built a very successful career as a rhetorician and teacher, and in worldly terms is thriving. However, he absolutely does not have it all figured out. As an adolescent he read Cicero's Hortensius and it turned his life around, kindling in him a passionate love of philosophy and starting him on an ardent search for truth (the episode is recounted in [1], III 4.7-4.8). On this search he has spent a number of years among the Manichees, (a gnostic sect that proclaims good and evil to be divine powers permeating the universe and vying for the souls and fates of humans) but has become disillusioned with them. He has experimented with Platonic mysticism. He has toyed with astrology. And he has, under the influence of Ambrose of Milan, moved closer to Christianity, to the point that he is fully convinced of the truth of the Christian creed and longs to convert.

But he does not convert, and he is miserable. "I was attracted to the Way", he writes, "but the narrowness of the path daunted me, and I still could not walk in it" ([1], VIII 1.1). The daunting narrowness of the path has to do with sex. Augustine had lived for many years with a woman with whom he has a son. He loved her and was devastated when forced to send her away because she was an impediment to the marriage his family had arranged for him. He has had to wait two years until his fiancée is old enough to marry but, as he puts it "I chafed at the delay because I was no lover of marriage but a slave of lust," and in the meantime, although still heartbroken over the rupture with his son's mother, he has taken another concubine, "in no sense a wife" ([1], VI 15.25). He wants, deeply, to be a Christian, but he also wants, urgently, to have sex: the two desires are incompatible. (For reasons of time we pass swiftly over the reasons why Augustine takes it for granted that this is the case - to get too involved with them might derail us for hours, as would discussion of the fact that his fiancée is eleven, or that he praises his mother for holding her tongue so effectively that her husband never beat her. In the classroom, you have to pick your fights, if you possibly can. It is disappointing, in one sense, that my students typically let me get away with that, but it is a relief none the less.)

Augustine, naturally, reflects deeply on his predicament: on the conundrum of harboring two incompatible desires. "I was aligned with both", he says, "but more with the desires I approved than with those I frowned upon, for these latter I was not really the agent, since for the most part I was enduring them against my will rather than acting freely. All the same, the force of habit that fought against me had grown stronger by my own doing, because I had come willingly to this point where I now wished not to be" ([1], VIII 5.10).

Here, as before, students' initial reaction is typically that Augustine is getting all bent out of shape because "back then" people were very uptight about sex whereas nowadays we know not to make such a big deal of it. That sex happens to be Augustine's issue is initially a problem as it distracts the students from getting to the heart of the matter. I have found the best way to help them past it, so that they can engage with the text is to spend some time exploring the nature of addiction. Our translation does not use the term, but students can generally produce it with little prompting. It is a concept that they engage with regularly, as most of them have experience at second or third hand (and generally at least one student in every class at first hand) with some form of chemical addiction, and are well aware of its destructive potential.) 
After some discussion, I distribute index cards again, and ask them to write down an addiction they have: a habit whose force routinely overpowers the free exercise of their will, preventing them from acting in ways that they really want to, a pattern of behavior that, like Augustine's, was initially freely chosen, but has since taken on a life of its own, directing their actions while no longer offering significant satisfaction. Essentially, I tell them "think of something you do a lot, that nobody makes you do, and that you really wish you could stop doing". I lead the way by sharing my own addictive pattern of fault-finding and criticizing and its consequences in my personal relationships. Again, the room is silent and intensely focused, both while the students write, and later, when we read aloud all of the shuffled and redistributed notes. Some students write just a word or phrase. There are a few chemical addictions - alcohol, tobacco, pot. A number invariably identify video games, which for many present a significant impediment to their being the kind of students they want to be, and getting the sort of grades that will help them get where they want in life. The most interesting ones, at least to me, are longer, and that describe addictive habits in interpersonal relationships-being jealous, being insecure, picking fights. This activity, like the first, counteracts the students' tendency to keep the Confessions at arm's length, to focus on the difference between them and Augustine, and thus to dismiss his reflections on his experience as irrelevant to their own lives and concerns. It helps them to see that, although Augustine's account of his divided will may seem alienating and extreme, it expresses an experience which they all have, and which they, in their own way, find frustrating and troublesome.

The final exercise in the series grows directly out of this and, due to the place of Augustine in my syllabus, occurs early in, or just before, Lent. I have learned over the years that a good number of my students, including those who profess very little in the way of religious belief or practice, habitually take on some sort of Lenten fast. Typically this involves giving up junk food, but junk food is something that very few students mention during the "name your addiction" exercise. In the Lenten Addiction Challenge I ask them to design a fast related to the addiction they mentioned, and to journal about it for the duration of Lent. (The instruction sheet which I give to my students is appended to this article.)

I cannot do justice within this essay to the variety of results this exercise has produced. A few examples, however, may serve to give the reader a sense of the results. A student who began with the fairly conventional goal of quitting smoking failed to do so, but realized through the course of the exercise that she used smoking as a mechanism for coping with stress, and by the end had identified a number of stressors in her life that triggered her reaching for a cigarette, and was taking steps to reduce them. Another student, who named as his addiction a perfectionism that lead to crippling procrastination, came gradually to understand and describe it not as an intellectual or emotional issue but rather as a spiritual one. "God is perfect", he wrote, "and that means I don't have to be". By the end of the exercise this insight had actually won him a considerable degree of freedom from the problem. One young man identified his addiction as picking fights with his girlfriend when they spoke on the phone. His journal showed his growing awareness of his motivations, of the needs and impulses that prompted him to introduce difficulty and drama into these conversations. These are by a large margin the most interesting student work I read all semester-as highly individual as the stacks of essays are undistinguished. 
I will conclude this essay with a survey of the strengths and weaknesses of this series of pedagogic exercises as I see it. Let me begin with the latter. On might argue that the exercises constitute an invasion of the students' privacy unwarranted by the educational benefit. Although my Jesuit institution, as I mentioned earlier, actively encourages faculty to engage in formation of the student as a whole person, I am sensitive to the possibility here I might be veering too close to a line that should not be crossed.

I use several strategies to mitigate this. First, if the students are to engage with the exercises in a way that will render them meaningful and useful, they clearly have to feel safe. I have outlined above a number of the steps I take to protect anonymity by ensuring that everybody's "confessions" are treated equally, and that none can be traced back to their author. In addition, I invite students to follow me to the office if they wish, to watch me shred the papers as soon as the in-class exercises are completed. Second, I participate honestly myself. To admit one's weaknesses in private, let alone to expose them in public, is intimidating, and particularly so for people at our students' stage in life, when they are on the brink of the "real world" and anxious about how they will manage when they get there. The least I can do, if I am asking them to do something uncomfortable, is to join in myself, and hopefully to show that not only in the 4th century but also in the 21 st one can function successfully as an adult while still vexed with struggles, conflicts and inconsistencies. Third, I make clear that although the Lenten Addiction Challenge grows out of a Christian text, and is linked to the Christian calendar, it is only as "religious" as they want it to be, and that they are free to parse it as an exercise in self-knowledge and self-mastery. Augustine found the end of his struggles in a relationship with God, and the whole text, written in the second person is a testament to that. Naturally, we treat the religious dimensions of the text thoroughly, but I assure them that the last thing I want is for students who do not have a personal faith commitment to fake some sort of piety. Fourth, I offer an alternative assignment that requires a regular practice of silence, and is also designed to encourage them in a discipline of reflection and self-awareness (the syllabus description of this alternative exercise is also appended to this essay.)

The other weakness of the exercise is that there is no way of confirming that students are actually engaging with it. I am open about this. With a view to perhaps defusing the temptation, I tell them that of course if they really want to they can "cheat" and just make something up, both for the in-class exercises and for the Lenten Addiction Challenge but I stress that there is nothing to be gained from it. Both the Challenge and the alternative assignment are pass-fail: students will accomplish nothing by manufacturing the sort of response that they might imagine I, or Augustine, would particularly value, and it is much less trouble, as well as far more useful for them, simply to tell the truth.

As for the strengths of the series of exercises, I see two. First, it exposes students to habits that promote reflection and self-knowledge. This, I believe, is in itself a valuable part of their education. Our students have been formed in a culture that discourages the hard work of genuine introspection: renders it, in fact, extraordinarily difficult by making distraction constantly and intrusively available. Many of them are rarely alone, rarely silent - both valuable if not essential conditions for self-reflection - and many of them will openly confess that they regard solitude and silence as alien and even frightening and are unlikely to undertake self-examination in any sustained way unless they are initially required to.

These exercises provide them with structured and contained opportunities to reflect on some aspects of the human condition: the complexity of our motivations, the weakness and conflicts in our wills. 
Because these aspects arise out of a text, the experience is a shared one: shared not only with the classroom but also across the centuries. My hope is that this communal aspect will render some of these experiences at least less intimidating, if no less troubling. Students are not alone in their conflicts, inconsistencies and addictions. My hope, further, is that students will find these experiences liberating and enriching, or at the least intriguing, and may be encouraged to continue some habit of self-reflection after the end of the class. Although there is no reliable way of verifying students' sincerity, it is certainly the case that a number of students close their journals by saying that, although they began it grudgingly they have found the habit of writing helpful and would like to continue it.

The first strength of the exercises I have described, then, lies in encouraging students to undertake a valuable personal practice in a context created directly by the reading of a class text. The second strength, I believe, lies in the effect of this experience on the students' reading of the text. The goal of the exercises, as I said at the beginning of this article, is to render Augustine more "relatable". Students are inclined, quite understandably, to find the huge historical and cultural gap between them and Augustine unbridgeably alienating. Someone from such a strange and distant world can surely have little in common with them, and only the most academically-minded among them- those students who find ideas inherently interesting and are eager to encounter them in any context - are inclined to approach the Confessions as anything other a hoop they are required to jump through. A lecture on Augustine's pivotal role in the development of the Western understanding of the nature of the self, or professorial assertions to the effect that we have all grown up a world significantly shaped by Augustine and his ideas, will likely interest only the same coterie of students.

The exercises, therefore, are designed to lessen the gap between Augustine and the students, including those not naturally drawn to historical texts in theology, by guiding them while they explore elements of their experience that echo those Augustine recalls and reflects on. If students thereby come to find Augustine more "relatable"-if they find some point of contact between his concerns and their own - they are opened to the possibility that the book as a whole might have something to offer them. Moreover, if Augustine, who articulates conflicts and perplexities they also experience, finds in theology a useful tool for addressing those conflicts and perplexities perhaps it might have something to offer them too.

I have not collected quantifiable assessment data on these pedagogic exercises - I do not know how one would do so. However, my experience has certainly been that since I have implemented them, this section of the class has gone much better. My students have been less likely to dismiss Augustine as coming from a world so utterly different from theirs that his concerns can have no possible bearing on theirs. They have been more open to discussing the issues he raises, and they have even been somewhat more ready to consider theology as a dynamic enterprise, worth engaging in. As distasteful as the term "relatable" may be, it indicates what can be a powerful pedagogic tool. A little classroom time devoted to these simple exercises has the potential, at least, to draw students into a fruitful engagement with one of the great texts of the Western tradition and even with the discipline of theology. 


\section{Appendix: Syllabus Description}

Spiritual Exercises. Read Instructions Carefully, and Choose ONE.

\section{Lenten Addiction Challenge}

While discussing Augustine, you identified a personal addiction: a habit that regularly keeps you from making the choices that you really want to and pursuing the goals where you believe your true happiness lies.

Your assignment during the season of Lent, is to design a "fast" related to this addiction. Set a goal that is realistic, but will be genuinely challenging, and that will force you regularly to confront your addiction. The purpose is to help you to understand what feeds and energizes your addiction, to come to greater understanding of its role in your life, and to lessen its hold on you.

If you are a Christian, or understand yourself to be in a relationship with God, you should approach this prayerfully, asking for help and support. If you are not, it will be a useful exercise in self-knowledge and self-mastery.

You should keep a journal for the duration of the exercise. This can be no more than a few lines, noting how you did in relation to your goal, though you may find it useful to write more. Once a week (pick a day and stick to it), your journal entry should be a little longer and should review and analyze the past week.

\section{Silence}

You will engage in a regular practice of silence. You will begin with a minimum (you can do more) of 3 min, 5 times a week. By week 3, you should be up to a minimum of 5 min, 6 times a week.

During this time, you are to be silent and in silence. Go somewhere where you can be by yourself and turn everything off. No phone, texts, iPod, book, pen, paper, tv, no conversation, no nothing. Your goal during this period is simply to be in your own skin, and to come to know where your mind and emotions go when they are alone with themselves with no external stimuli or distractions. What thoughts, feelings, memories, anxieties, daydreams float to the surface?

You should keep a journal. At the very minimum, keep a record of when and where you practiced silence, and write a few words for each session, noting what your primary thoughts or concerns were during that time. Once a week (pick a day and stick to it), your journal entry should be a little longer and should review and analyze the past week.

For BOTH OPTIONS you will show me your journal, and turn in an 1-2 page informal essay, describing your experience during the exercise and discussing what, if anything, you learned from it.

\section{Acknowledgments}

This paper was given at the conference on Teaching that Christian Intellectual Tradition at Samford University, October, 2014. My thanks are due to the organizers of the conference. 


\section{Conflicts of Interest}

The author declares no conflict of interest.

\section{References}

1 Saint Augustine. The Confessions. Translated by Maria Boulding. New York: New City Press, 2012.

(C) 2015 by the author; licensee MDPI, Basel, Switzerland. This article is an open access article distributed under the terms and conditions of the Creative Commons Attribution license (http://creativecommons.org/licenses/by/4.0/). 